\title{
Problems and perspectives of sustainable trade development in China under the one belt one road initiative
}

\author{
Zhi $\mathrm{Ji}^{1,{ }^{*}}$, George Abuselidze ${ }^{2}$, and Valeriia Lymar ${ }^{1}$ \\ ${ }^{1}$ Vasyl' Stus Donetsk National University, 600-richia Street, 21, Vinnytsia, 21021, Ukraine \\ ${ }^{2}$ Batumi Shota Rustaveli State University, 35 Ninoshvili Str., Batumi, 6010, Georgia
}

\begin{abstract}
In the paper the authors proved that China's growth towards dominance in international trade has begun recently, but, on average, the growth of China's trade volume has doubled every four years over the past three decades. The paper analyses that the rapid growth of the Chinese economy provides all countries around the world especially neigh boring countries, with a chance of interconnected development, which had a decisive impact on the economic prosperity of the world economy at the end of the last and at the beginning of this century. The key priority of Chinese economic policy was called attracting FDI, but gradually it focused on foreign direct investment (FDI) from China. Therefore, the "one belt, one road" initiative has brought maximum effect not only on the country itself, but on the entire global economy, and has become the basis for multilateral economic development. Accordingly, we have come to the conclusion that the project the "one belt, one road" has a goal to strengthen the geopolitical cooperation between Asia and Europe, so it is Ukraine that is important in its implementation. Ukraine is a strategically important logistics hub between Asia and Europe. It is proved that Ukraine is now a promising country in Eastern Europe and has a significant deferred purchasing power potential, which will increase if the political and economic situation in the country stabilizes.
\end{abstract}

\section{Introduction}

In the modern world, with its level of economic development, any country depends on its position on the world stage, and one of the most important missions is the effective implementation of the foreign trade policy. Depending on how the foreign trade strategy is developed, the direction in which the country is moving (protectionism or open-door policy) and such external economic results will affect the world trade, and this, in turn, will affect the economic situation in the country.

The end of the XX - the beginning of the XXI century was marked by a vivid manifestation of the fact that one of the leading factors of global development, a powerful engine of globalization was the Chinese economy. On the background of the negative impact of the global financial crisis of 2008-2010 in most countries of the world, China

* Corresponding author: george.abuselidze@gmail.com 
proved to be most sustainable, steady, and capable of confident development, although at a slightly slower pace. Owing to China the center of the world progress has begun to move from Western Europe and North America to China.

The peculiarities of the course of globalization processes indicate that China, under the slogan of an open peace-loving policy, is actually strengthening the focus of its political and economic activities on transforming the existing unipolar world, led by the United States, into a multipolar world. The goal of China's foreign policy is to achieve the status of a super state by the middle of the XXI century.

The transformation of China into the second most important center of the world politics promotes the Chinese leadership's ambitious economic and political projects aimed at reformatting the entire international economic system following the growing capabilities and needs of the country. In this regard, in 2013, the fifth generation of Chinese leaders put forward the strategic initiative "one belt, one road", which can be called China's foreign policy concept for countries from Western Europe to Southeast Asia. The goal of the project is accelerating development of China in the face of new challenges on the international arena. These challenges include reduced export opportunities in the traditional markets of the United States, the European Union, and East Asia due to a decline in global economic growth and attempts by the United States to weaken China's political and economic positions.

Consequently, the development of the foreign trade strategy of China deserves attention, because almost 40 years ago, due to the simple changes in the foreign trade of the country, which continues to this day, it has achieved impressive results and occupies a primary place in the world economy.

\section{Research methods}

\subsection{Literature review}

The works of such outstanding domestic and foreign researchers as P. Bożyk, V. Chernyshenko, Y. Vertakova, V. Mkrttchian, I. Chubarov, D. Kalashnikov, S. K. Coulibaly, C. Erbao, T. M. Mekongcho, X. Cui, M. Yu, K. Han, L. Y. He, X. Lin, Z. Zhang, L. Prystupa, A. Raišienè, W. Xiuli, A. Ying-min, Z. Zheng, J. Zheng, M. Zhengang and others are devoted to the problems of China's foreign trade policy in the context of economic globalization [1-12]. China's foreign trade has been the subject of research by Chinese scholars M. Han, G. Chen, R. Hsueh, Z.H.Jian-rong, F. Lemoine, D. Unal, M. Dunford, X. Liu, Y. Liu, L. Pen, T. Summers, L. Sun, R. Varfalovskaya, L. Xing, J. Zhang and T. Zhyber, Y. Liu, M. Zhengang [13-27]. The study of the Ukrainian-Chinese cooperation was carried out by domestic scientists O. Bordilovska, V. Ugwu, T. Fomenko, M. Bilotserkovets, Zh. Henglong, Zh. Zhenzhen, X. Jian, K. Jie, O. Kratt, K. Pryakhina, M. Bilyk, M. Levchenko, A. Pochtovyuk, I. Smyrnov, L. Ukrayinets, V. Venger, S. Zakharin, among others [28-38]. The lack of scientific developments, devoted to the outlined problem with an emphasis on new promising areas of research, determined the relevance and choice of the research topic.

\subsection{Research instruments}

The theoretical basis of the research is the scientific works of domestic and foreign scientists; the institutional basis (legislative acts, strategic programs, and regulatory documents); data from the state statistics service of Ukraine, the National Bureau of statistics of China; materials and analytical reports of international organizations and 
research agencies (World Bank, IMF, international trade center UNCTAD / WTO, among others); materials of non-governmental trade organizations (Ukrainian Chamber of Commerce and Industry, International Chamber of Commerce "Silk Road"). Comparative, historical, institutional, and functional research methods were used, as well as a factorial approach when considering issues related to the implementation of the "one belt, one road" project.

The spatial-organizational approach to the analysis of the world politics is applied. Consideration of the foreign policy approaches to the development of the strategic partnership between Ukraine and China is based on the analysis of official documents and statements of officials, as well as the most significant publications.

At the level of general scientific methodology, methods of theoretical generalization, analysis and synthesis, abstract-logical, economic-mathematical modelling, comparative and expert assessments, as well as methods of logical, system-structural analysis of economic processes and relationships, statistical, comparative, factor and structural, sectorbranch and dialectical approaches were applied.

The objective is to investigate the specifics of the implementation of the "one belt, one road" initiative and Ukraine's participation in it, analyse the investment attractiveness of Ukraine for China and suggest prospects for creating a free trade zone between China and Ukraine within the framework of the "one belt, one road" initiative.

\section{Results and discussion}

\subsection{Features of the Implementation of the One Belt, One Road Initiative}

China is the world's largest producer of goods and exporter, whose influence on world trade is constantly increasing. In recent years, China has completed the modernization of production and continues the process of reorienting its export flows from cheap consumer goods and semi-finished products to ready production with a high technological component, which leads to increased competition of Chinese manufacturers into the traditional foreign markets of Ukraine.

Today, China has one of the world's largest investment potential and is the most anticipated global investor for the next few years. China is an example for many developing countries. Thanks to the implementation of the government's "one belt, one road" initiative, other states have the opportunity to borrow Chinese experience in conducting a foreign policy that is aimed at peaceful life and sustainable development.

Increasing the level of dependence of the national economy on external influences actualizes the issue of creating a geo-economic strategy for the development of the state as a full-fledged subject of the world economic processes to increase the effectiveness of multilateral cooperation and broad participation in international and regional integration projects.

Ukraine is an important hub along the "one belt, one road", and its participation in the construction of the initiative has significant advantages in the development of the trade and economic cooperation between the two countries: low market cost, low labor cost, good conditions for the placement of units, as well as a strong scientific, technical, industrial and agricultural basis. A considerable quantity of companies with Chinese capital demonstrates significant interest and enthusiasm for trade and economic cooperation with Ukraine.

China's peaceful foreign policy, its contribution to the development of the world economy, and the confrontation in international relations are gradually bringing China closer taking a central place on the world stage, becoming a universally recognized builder of the international peace, contributing to global development, and a defender of the world 
order. Even with a gradual slowdown in growth, China could become the world's largest economy by 2030 [39].

The steady growth of the Chinese economy is the main driving force of the global economic recovery. Over 40 years of the reform and openness policies, the share of the Chinese economy in the world economy has grown continuously [30].

\subsection{Role of the One Belt - One Road Initiative Before and After the Pandemic}

According to the World Bank's Global Economic Prospects report (GEP), global economic growth is generally expected to slow to a moderate level from $3 \%$ in 2019 to $2.9 \%$ in 2019 and level off at $2.8 \%$ in 2021-2022 [40].

In 2021 , the economic growth in developed countries is expected to be $2 \%$, and in developing countries and emerging markets $-4.2 \%$. In 2021-2022, the growth rates will be $1.6 \%$ and $1.5 \%$ in developed countries, respectively, and $4.5 \%$ and $4.6 \%$ in developing countries, respectively $[38,40]$, (see Table 1 ).

Table 1. World GDP growth rates in 2017-2019 and forecast for 2021-2022 \%.

\begin{tabular}{|l|c|c|c|c|c|c|}
\hline & $\mathbf{2 0 1 7}$ & $\mathbf{2 0 1 8}$ & $\mathbf{2 0 1 9}$ & $\mathbf{2 0 2 0}$ & $\mathbf{2 0 2 1}$ & $\mathbf{2 0 2 2}$ \\
\hline World & $\mathbf{2 . 4}$ & $\mathbf{3 . 1}$ & $\mathbf{3 . 0}$ & $\mathbf{2 . 9}$ & $\mathbf{2 . 8}$ & $\mathbf{2 . 8}$ \\
\hline Developed Countries & $\mathbf{1 . 7}$ & $\mathbf{2 . 3}$ & $\mathbf{2 . 2}$ & $\mathbf{2 . 0}$ & $\mathbf{1 . 6}$ & $\mathbf{1 . 5}$ \\
\hline USA & 1.6 & 2.2 & 2.9 & 2.5 & 1.7 & 1.6 \\
\hline Eurozone & 1.9 & 2.4 & 1.9 & 1.6 & 1.5 & 1.3 \\
\hline Japan & 0.6 & 1.9 & 0.8 & 0.9 & 0.7 & 0.6 \\
\hline $\begin{array}{l}\text { New Markets and Developing Countries } \\
\text { (EMDE) }\end{array}$ & $\mathbf{3 . 7}$ & $\mathbf{4 . 3}$ & $\mathbf{4 . 2}$ & $\mathbf{4 . 2}$ & $\mathbf{4 . 5}$ & $\mathbf{4 . 6}$ \\
\hline East Asia and the Pacific & 6.3 & 6.6 & 6.3 & 6.0 & 6.0 & 5.8 \\
\hline PRC & 6.7 & 6.9 & 6.5 & 6.2 & 6.2 & 6.0 \\
\hline Indonesia & 5.0 & 5.1 & 5.2 & 5.2 & 5.3 & 5.3 \\
\hline Thailand & 3.3 & 3.9 & 4.1 & 3.8 & 3.9 & 3.9 \\
\hline Europe and Central Asia & 1.7 & 4.0 & 3.1 & 2.3 & 2.7 & 2.9 \\
\hline Russia & -0.2 & 1.5 & 1.6 & 1.5 & 1.8 & 1.8 \\
\hline Turkey & 3.2 & 7.4 & 3.5 & 1.6 & 3.0 & 4.2 \\
\hline Poland & 3.1 & 4.8 & 5.0 & 4.0 & 3.6 & 3.3 \\
\hline Latin America and the Caribbean & $\mathbf{- 1 . 5}$ & $\mathbf{0 . 8}$ & $\mathbf{0 . 6}$ & $\mathbf{1 . 7}$ & $\mathbf{2 . 4}$ & $\mathbf{2 . 5}$ \\
\hline Brazil & -3.3 & 1.1 & 1.2 & 2.2 & 2.4 & 2.4 \\
\hline Mexico & 2.9 & 2.1 & 2.1 & 2.0 & 2.4 & 2.4 \\
\hline Argentina & -1.8 & 2.9 & -2.8 & -1.7 & 2.7 & 3.1 \\
\hline Middle East and North Africa & $\mathbf{5 . 1}$ & $\mathbf{1 . 2}$ & $\mathbf{1 . 7}$ & $\mathbf{1 . 9}$ & $\mathbf{2 . 7}$ & $\mathbf{2 . 7}$ \\
\hline South Asia & $\mathbf{7 . 5}$ & $\mathbf{6 . 2}$ & $\mathbf{6 . 9}$ & $\mathbf{7 . 1}$ & $\mathbf{7 . 1}$ & $\mathbf{7 . 1}$ \\
\hline India & 7.1 & 6.7 & 7.3 & 7.5 & 7.5 & 7.5 \\
\hline Pakistan & 4.6 & 5.4 & 5.8 & 3.7 & 4.2 & 4.8 \\
\hline Bangladesh & 7.1 & 7.3 & 7.9 & 7.0 & 6.8 & 6.8 \\
\hline Africa South of the Sahara & $\mathbf{1 . 3}$ & $\mathbf{2 . 6}$ & $\mathbf{2 . 7}$ & $\mathbf{3 . 4}$ & $\mathbf{3 . 6}$ & $\mathbf{3 . 7}$ \\
\hline & & & & & \\
\hline
\end{tabular}

According to the expectations of the majority of experts, the main economic growth in 2021-2022 is associated with China, the Asia-Pacific region, and the South Asia region as a whole which will show growth rates that are significantly ahead of the average world level. Only the regions of the Middle East, Africa, and Latin America will reach a level that slightly exceeds the global average GDP growth rate. The other part of the world regions (countries), including North America, Europe, and Russia, will significantly concede the leaders in terms of GDP growth and lag behind the global average [40-46]. 
The state statistical administration of China reports that in 2019, the country's economic growth rate of GDP was $6.5 \%$, which is the lowest since 1990, that is, for the last 28 years. In 2018, the growth rate of the Chinese economy reached $6.9 \%$. According to the World Bank, the fall in the rate of growth will continue before the improvement begins. In 2020 2021 , we expect a further slowdown to $6.2 \%$, and in 2021 to $6 \%$. Among the reasons associated with the decline in the growth rate of China, experts named the trade war with the United States, COVID-19, as well as weak domestic demand and investment activity [40-43, 47, 48].

It is worth admitting that China's growth towards dominance in international trade began quite recently, however, on average, the growth of China's trade volumes has doubled every four years for the past three decades. And today, every tenth dollar in international trade flows through China. In the period from 1978 to 2019, the average growth rate of the China's economy was about $9 \%$, but recently it has slightly decreased [40].

Total retail sales of consumer goods of China in 2019 reached 380,870,000,000 Yuan, increasing by $9 \%$ compared to 2018 . At the same time, online sales in 2019 increased by $23.9 \%$, to 9 trillion Yuan, this figure showed an increase of $32.2 \%$ in 2018 . Retail sales in urban areas increased to $325,600,000,000$ Yuan in 2019 ( $+8.8 \%$ compared to $10 \%$ in $2018)$, and in rural areas - to $55,300,000,000$ Yuan $(+10.1 \%$ compared to $11.8 \%$ last year) [49].

Investment in fixed assets of China in 2019 increased by $5.9 \%$, to $635,600,000,000$ Yuan. The growth of investment in agricultural enterprises was $12.9 \%$, in industry- $6.2 \%$, in services $-5.5 \%$. Meanwhile, in 2018, investment increased by $7.2 \%$, to 61300000000000 Yuan. Besides, by the end of 2019, the population of China grew by 5300,000, to 1395000000 people [49].

The real allocated income per capita of China in 2019 was 28,228 Yuan, this figure increased by $8.7 \%$ compared to the previous year. At the same time, the income among the urban population reached the level of 39,251 Yuan $(+7.8 \%)$, and among rural residents 14,617 Yuan $(+8.8 \%)$. The consumer price index in China for 2019 increased by $2.1 \%$. Food price increased by $1.9 \%$, medical services by $4.3 \%$, clothing by $1.2 \%$, housing by $2.4 \%$, transport by $1.7 \%$, and consumer goods by $1.6 \%$.

In 2018, the average annual contribution of the Chinese economy to global growth reached $33.2 \%$, ranking first in the world. In the same period, the USA and European deposits made up 16.8\% and 4.4\%, respectively [40] (see Table 2).

Table 2. Contribution of China and the United States to the world economy in 2013-2019. Source: Compiled by the author according to the World Bank (WB).

\begin{tabular}{|c|c|c|c|c|c|c|c|}
\hline & $\mathbf{2 0 1 3}$ & $\mathbf{2 0 1 4}$ & $\mathbf{2 0 1 5}$ & $\mathbf{2 0 1 6}$ & $\mathbf{2 0 1 7}$ & $\mathbf{2 0 1 8}$ & $\mathbf{2 0 1 9}$ \\
\hline PRC & $31.7 \%$ & $32.5 \%$ & $29.7 \%$ & $30.0 \%$ & $30.5 \%$ & $33.2 \%$ & $35.2 \%$ \\
\hline USA & $20.4 \%$ & $15.2 \%$ & $19.6 \%$ & $21.9 \%$ & $16.3 \%$ & $17.8 \%$ & $17.9 \%$ \\
\hline
\end{tabular}

Respectively, the US contribution to the growth of the world economy in this period will be about $17.9 \%$, the contribution of China - 35.2\%, the Eurozone $-7.9 \%$, India $-8.6 \%$, Indonesia $-2.5 \%$, and South Korea - $2 \%$. The contribution of other countries to global economic growth over this period will be less than $2 \%$. For example, the contribution of Australia is $1.8 \%$, Canada $-1.7 \%$, Great Britain -1.6\%, Russia -1\% [40] (see Figure 1). 


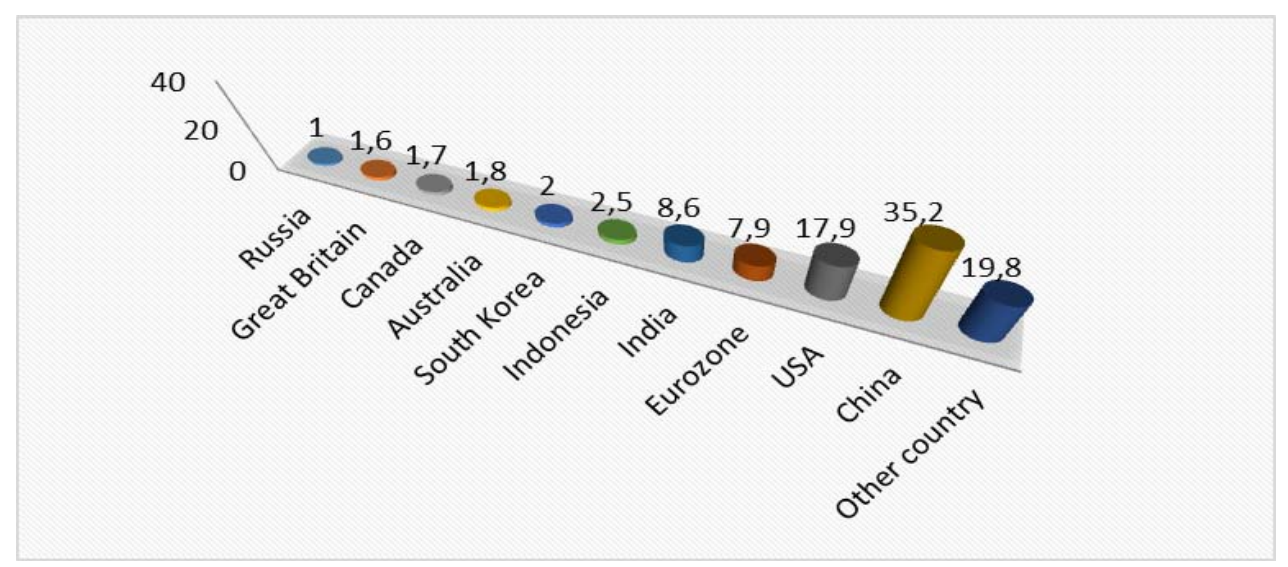

Fig. 1. Average Annual contribution of countries to the world economy in 2017-2019, (\%). Source: Compiled by the author according to the World Bank (WB).

According to the industrial competitiveness index in 2017, China became the most competitive country in the industrial production sector. The country also maintained leading positions in previous surveys of the World industrial competitiveness index for 2010 and 2013. However, the global company executives predict that in the next five years it will move to the second position.

Table 3. The global competitive industrial performance index in 2017, and forecast for 2020. Source: Compiled by the author based on data from Deloitte.

\begin{tabular}{|c|c|c|c|c|c|}
\hline \multicolumn{3}{|c|}{$\mathbf{2 0 1 7}$} & \multicolumn{3}{|c|}{$\mathbf{2 0 2 0}$} \\
\hline Position & Country & Index value & Position & Country & Index value \\
\hline 1. & PRC & 100 & 1. & USA & 100 \\
\hline 2. & USA & 99.5 & 2. & PRC & 93.5 \\
\hline 3. & Germany & 93.9 & 3. & Germany & 90.8 \\
\hline 4. & Japan & 80.4 & 4. & Japan & 78 \\
\hline 5. & South Korea & 76.7 & 5. & India & 77.5 \\
\hline 6. & Great Britain & 75.8 & 6. & South Korea & 77 \\
\hline 7. & Taiwan & 72.9 & 7. & Mexico & 75.9 \\
\hline 8. & Mexico & 68.5 & 8. & Great Britain & 73.8 \\
\hline 9. & Canada & 68.7 & 9. & Taiwan & 72.1 \\
\hline 10. & Singapore & 68.4 & 10. & Canada & 68.1 \\
\hline
\end{tabular}

Accordingly, the world history has not yet known the scale and pace of the industrialization and urbanization that took place in China. The rapid growth of the Chinese economy gives all countries of the world, especially neighboring countries, a chance for interconnected development having a decisive impact on the economic prosperity of the world economy at the end of the last and beginning of this century.

In the next few years, China will continue to play an important role as a "powerful engine" in the recovery of the global economic growth. Of course, global economic growth cannot rely solely on the Chinese contribution. China appeals to all countries of the world, especially leading economically, to take the initiative to follow its course, strengthen cooperation, work hand in hand, stimulate trade and investment, and strenuously promote structural reforms jointly making efforts to create an innovative, dynamic and tolerant 
world economy. China has chosen an economic development strategy aimed at raising the standard of living within the country and spreading its influence and strengthening as a world power. According to China's foreign policy, it is becoming more active, as required by the national interests of the world's second (and soon first) economy.

Until recently, attracting FDI was officially considered a key priority of Chinese economic policy, but the focus has gradually shifted to foreign direct investment (FDI) from China. The "one belt, one road" initiative has already become a factor of the global growth and opened up new opportunities for the global development. The countries participating in the initiative account for $13.4 \%$ of the world trade, and the total volume of the trade between China and the member countries of the initiative exceeded 6 billion U.S. dollars. Today, it is clear that the initiative is needed not only by China itself but by all participating countries. The General slogan of the second forum - "jointly build ,one belt, one road" open a great future" - was also relevant. It indicated that without the efforts of all participants, it would be difficult to achieve the ultimate goal: to work for the development and prosperity of all mankind, to gain mutual benefit.

At the same time, China does not strive to impose development models for others because of the "one belt, one road" initiative. However, it considers the initiative as a platform where it can share some of its development experience with the rest of the world. At this stage, China only reserved the right to set institutional standards for the initiative, which, instead of meeting current international standards, would be open to it [50]. While China is entering a new stage of in-depth reforms and openness, it is important for Beijing in the future to make efforts ensuring that the "one belt, one road" initiative brings maximum effect not only for itself, but for the entire global economy, and becomes the basis for multilateral economic development.

The goal of the "one belt, one road" project is to strengthen the geopolitical cooperation between Asia and Europe, so it is Ukraine that is important in its implementation. Ukraine is a strategically important logistics hub between Asia and Europe. The best approach to the further development of the Chinese Express to Europe is to create routes through Ukraine. Ukraine offers its Chinese colleagues a common project portfolio: development of the port infrastructure, alternative energy facilities, construction of highways and bridges, development of railway and airport facilities, high technologies, cooperation in the aerospace sphere, processing of agricultural products [31, 51].

Bilateral investment cooperation does not yet match the capabilities of China and the needs of Ukraine. The increase in import volumes from China is not accompanied by an increase in investment cooperation $(0.48 \%$ of the total volume of attracted foreign direct investment), and Ukrainian investments in China are also practically absent [25]. In the economy of Ukraine attracted 17800000 US dollars investments from China are mainly directed to enterprises in the field of agriculture, forestry and fisheries $-39.6 \%$, industry $19.4 \%$, wholesale and retail trade, repair of motor vehicles and motorcycles $-11.2 \%$, transport, warehousing, postal and courier activities - $11 \%$.

In order to determine the main factors affecting the strategic development of the economic partnerships between Ukraine and China in the period up to 2030 inclusively, SWOT analysis was conducted. Based on this analysis, external opportunities and threats for strategic cooperation between countries were identified, as well as their strengths and weaknesses (see Table 4). 
Table 4. SWOT analysis of Ukraine's trade and economic cooperation with China.

\begin{tabular}{|c|c|c|}
\hline & Opportunities ( O ) & Threats (T) \\
\hline $\begin{array}{l}\text { External Factor } \\
\text { (China) } \\
\text { Internal Factors } \\
\text { (Ukraine) }\end{array}$ & $\begin{array}{l}\text { 1. Expanding cooperation } \\
\text { between countries in the } \\
\text { framework of the " } 16+1 " \\
\text { Initiative and the "one belt, one } \\
\text { road" project. } \\
\text { 2. Conclusion of an agreement } \\
\text { and creation of a free trade zone } \\
\text { between Ukraine and China. } \\
\text { 3. Entering the market and } \\
\text { determining sectoral priorities } \\
\text { for the trade and economic } \\
\text { cooperation. }\end{array}$ & $\begin{array}{l}\text { 1. Technological asymmetries } \\
\text { in trade countries: raw material } \\
\text { imports from Ukraine and } \\
\text { high-tech exports from China. } \\
\text { 2. Limited access of domestic } \\
\text { business to the Chinese market. } \\
\text { 3. Maintaining a negative } \\
\text { balance in foreign trade for } \\
\text { most product groups. } \\
\text { 4. High level of tariff } \\
\text { protection, especially for } \\
\text { agricultural products. }\end{array}$ \\
\hline Strengths (S) & Anticipation $(\mathrm{S}+\mathrm{O})$ : & Anticipation $(S+T)$ : \\
\hline $\begin{array}{l}\text { 1. Favorable geographical } \\
\text { location of Ukraine. } \\
\text { 2. Rich in natural } \\
\text { resources. } \\
\text { 3. High level educational } \\
\text { potential. } \\
\text { 4. Availability of } \\
\text { scientific and } \\
\text { technological potential. }\end{array}$ & $\begin{array}{l}\text { Full liberalization of the trade } \\
\text { mode, strengthening of trade } \\
\text { and economic relations, the } \\
\text { possibility of creating a free } \\
\text { trade zone, strengthening of } \\
\text { pragmatics in trade and } \\
\text { economic relations in order to } \\
\text { establish a symmetrical } \\
\text { economic interdependence of } \\
\text { the parties. }\end{array}$ & $\begin{array}{l}\text { Increasing the gap between } \\
\text { production and technological } \\
\text { capabilities of the countries, } \\
\text { growth of demand for imported } \\
\text { products in the domestic } \\
\text { market, growth of dependence } \\
\text { in the sector of commodity } \\
\text { exports to China, lack of } \\
\text { commodity exports and } \\
\text { geographical diversification of } \\
\text { Ukraine's exports. }\end{array}$ \\
\hline Weaknesses (W) & Anticipation $(\mathrm{W}+\mathrm{O})$ & Anticipation $(W+T)$ \\
\hline $\begin{array}{l}\text { 1. Armed conflict on the } \\
\text { territory of the country. } \\
\text { 2. The energy dependence } \\
\text { of the state. } \\
\text { 3. Low indicators in } \\
\text { social, political and } \\
\text { economic ratings. } \\
\text { 4. Low competitiveness } \\
\text { of domestic goods and } \\
\text { services. } \\
\text { 5. Instability of the } \\
\text { national currency } \\
\text { exchange rate. }\end{array}$ & $\begin{array}{l}\text { Reset of Chinese-Ukrainian } \\
\text { relations, giving these relations } \\
\text { a more active political } \\
\text { character, expanding trade and } \\
\text { economic cooperation between } \\
\text { the countries in order to protect } \\
\text { and promote national interests. }\end{array}$ & $\begin{array}{l}\text { Destabilization of bilateral } \\
\text { relations, demotivation of } \\
\text { business activities due to a } \\
\text { significant number of trade } \\
\text { barriers, mutual perception of } \\
\text { countries with regards of } \\
\text { threats, and reduction of } \\
\text { investment attractiveness of the } \\
\text { countries. }\end{array}$ \\
\hline
\end{tabular}

We can make a conclusion that based on the analysis, including SWOT, the strategic development of partnership relations in the economic sphere between Ukraine and China in the period up to 2030 should be based on three principles: First, we need to intensify and strengthen the dialogue on deepening of the trade and economic cooperation through a system of trade policy, primarily reducing the tariff and non-tariff protection of the Chinese market (for example, the tariff for wheat and corn is 65\%); second, optimization of the trade, economic and investment cooperation: for example, Ukraine as an Eastern European country should join the cooperation with China in the framework of the "16+1" Initiative and the "one belt, one road" project in order to gain leverage on the development of the global and European economic infrastructure, as well as explore the opportunities and threats of creating an FTA between the countries; third, the development of a long-term strategy for the development of the trade and economic cooperation between Ukraine and China with the identification and justification of sectorial priorities. 


\section{Conclusions}

So, the "Belt" can be considered as a China-centric project creating a network of partnerships in Eurasia using an extremely wide range of tools - from political and diplomatic coordination to financial mechanisms, from trade and economic instruments to expanding humanitarian cooperation. The documents published by the Ministry of Foreign Affairs and the Ministry of Commerce of China emphasize that the scale of the "one belt, one road" initiative will significantly go beyond the construction of infrastructure facilities. The program will also include financial integration, the internationalization of the Yuan, the establishment of links between regional information and communication technology networks (the "information silk road"), and the expansion of cross-border trade and investment. In General, there is a combination of traditional approaches for Chinese diplomacy (for example, respect for sovereignty and non-interference in internal Affairs) with a new emphasis on compliance with high standards and international norms, as well as determining the crucial role of the market and industry in the project implementation. Consequently, "one belt, one road" is a big strategy at the new stage foreign openness policy of China.

"One belt, one road" does not contain the idea of creating a free trade zone and does not provide for binding agreements between States. Instead, it is based on China's intention to use its economic resources and diplomatic tools to invest in infrastructure and economic projects, which should generally ensure closer ties with Asian and European countries. Using less formal mechanisms gives the project flexibility and allows Beijing to maximize its economic and political opportunities. The project of cooperation within the framework of the "one belt, one road" is not so much the result of negotiations as the result of the agreement through consultations, it is a new model for the development of cooperation. The Chinese government, after evaluating domestic and international factors taking into account the time and circumstances, proposed a new type of openness strategy, which consists of two important components - "reciprocity and overall gain" and geopolitical considerations. The strategic vision is that China should act as a responsible great power on the world stage. The essence of the "one belt, one road" initiative is that China must learn to be a constructive leader and give to the world community more international public goods. The "one belt, one road" directly concerns Europe, because, first of all, European companies are particularly interested in Chinese investors due to their high-tech level, innovative potential, know-how, and concentration skills; second, it is access to the European market; third, Europe is the endpoint of the Chinese New Silk Road.

As for Ukraine, the development of relations with China today necessarily implies both further expansion of bilateral relations, primarily based on the economic interests, and the necessity completely to join the "one belt, one road" project. Today Ukraine is a promising country in Eastern Europe and has a significant deferred purchasing power potential, which will increase if the political and economic situation in the country stabilizes. Reduction the tariff and non-tariff protection of the Chinese market should be considered a long-term priority in trade and economic cooperation; optimization of trade, economic and investment cooperation within the framework of the "16 + 1" initiative and the "one belt, one road" project in order to gain leverage on the development of the global and European economic infrastructure; determining the feasibility and advantages and dangers of creating an FTA between Ukraine and China. 
1. P. Bożyk, Globalization and the Transformation of Foreign Economic Policy, 223-243 (2019) doi:10.4324/9781351157124-9

2. V. Chernyshenko, Y. Vertakova, V. Mkrttchian, Avatar-Based Models, Tools, and Innovation in the Digital Economy, 131-140 (2020) doi:10.4018/978-1-7998-1104$6 . \operatorname{ch} 008$

3. I. Chubarov, D. Kalashnikov, Mirovaya ekonomika i mezhdunarodnye otnosheniya 62(1), 25-33 (2018)

4. S.K. Coulibaly, C. Erbao, T.M. Mekongcho, Technological Forecasting and Social Change 127, 271-280 (2018)

5. X. Cui, M. Yu, Political Economy of Globalization and China's Options, 207-226 (2018) doi:10.1163/9789004383944_015

6. K. Han, Impact of Economic Globalization on China's Social Welfare Policy. Social Welfare in Transitional China (Palgrave Macmillan, Singapore, 2020)

7. L.Y. He, X. Lin, Z. Zhang, Journal of Policy Modeling 42(3), 628-660 (2020) doi:10.1016/j.jpolmod.2020.02.001

8. L. Prystupa, V. Koval, I. Kvach, A. Hrymalyuk, Transformation of cycles of state regulation in international trade. Strategies, Models and Technologies of Economic Systems Management (SMTESM 2019) (Atlantis Press, 2019)

9. W. Xiuli, China's International Economic Development 30 Years. China International Economic Cooperation Association Writing Group (Xinhua Cultural Enterprises, Singapore, 2012)

10. A.N. Ying-min, Journal of Lanzhor University (Social Sciences) 3, 14 (2002)

11. Z. Zheng, Economic globalization and development of China's foreign economic cooperation and trade. China's Economic Globalization through the WTO (Routledge, 2017)

12. J. Zheng, C. Shen, China Political Economy 2(1), 136-156 (2019) doi:10.1108/cpe-042019-0003

13. M. Han, G. Chen, Land Use Policy 70, 521-534 (2018) doi:10.1016/j.landusepol.2017.07.022

14. R. Hsueh, Review of Policy Research 32(6), 627-648 (2015) doi:10.1111/ropr.12149

15. Z.H.U. Jian-rong, Journal of Nanjing Forestry University (Humanities and Social Sciences Edition) 4 (2003)

16. F. Lemoine, D. Unal, China \& World Economy 25(2), 1-21 (2017) doi:10.1111/cwe. 12191

17. Y. L. Li, B. Chen, M.Y. Han, M. Dunford, W. Liu, Z. Li, Journal of Cleaner Production 192, 950-960 (2018). doi:10.1016/j.jclepro.2018.04.230

18. X. Liu, J. Walsh, City University Research Journal 9(4), 776-787 (2019)

19. L. Pen, Russian foreign economic Bulletin 11 (2019)

20. T. Summers, Third World Quarterly 37(9), 1628-1643 (2016) doi:10.1080/01436597.2016.1153415

21. L. Sun, Proceedings of the International Conference on Education, Management and Computer Science (2016) doi:10.2991/icemc-16.2016.49

22. R. Varfalovskaya, Problemy Dalnego Vostoka 6, 85-91 (2018) doi:10.31857/s013128120002692-2

23. L. Xing, Mapping China's 'One Belt One Road'Initiative (Palgrave Macmillan Cham, 2019) doi:10.1007/978-3-319-92201-0_1 
24. J. Zhang, Energy Policy 129, 1111-1120 (2019) doi:10.1016/j.enpol.2019.03.020

25. T. Zhyber, Chinese Studies 1, 23-35 (2018) doi:10.15407/chinesest2018.01.023

26. Y. Liu, Journal of Physics: Conference Series 1533, 022064 (2020) doi:10.1088/1742$6596 / 1533 / 2 / 022064$

27. M. Zhengang, China's diplomacy: all-round development of a three dimensional framework. The Governing Principles of the Communist Party of China (Foreign Languages Press Co. Ltd, Beijing, 2012)

28. O. Bordilovska, V. Ugwu, Actual Problems of International Relations 138, 35-43 (2019) doi:10.17721/apmv.2018.138.0.35-43

29. T. Fomenko, M. Bilotserkovets, T. Klochkova, O. Statsenko, A. Sbruieva, O. Kozlova, D. Kozlov, Academic Journal of Interdisciplinary Studies 9(6), 157-157 (2020) doi:10.36941/ajis-2020-0120

30. Zh. Henglong, Zh. Zhenzhen, Ukraine-China 13, 94-110 (2018)

31. X. Jian, K. Jie, Ukraine-China 13, 76-78 (2018)

32. O. Kratt, K. Pryakhina, M. Bilyk, SHS Web of Conferences 39, 01014 (2017) doi:10.1051/shsconf/20173901014

33. M. Levchenko, A. Levchenko, International Journal 1 (2015)

34. A. Pochtovyuk, V. Semenikhina, SHS Web of Conferences 39, 01022 (2017). doi: $10.1051 /$ shsconf $/ 20173901022$

35. I.V. Smyrnov, P.I. Viblyi, S.V. Zakharin, Actual Problems of Economics 188(2), 38-43 (2017)

36. L. Ukrayinets, East European Science Journal 3, 43 (2019)

37. V. Venger, European scientific journal of Economic and Financial innovation 1, 4-13 (2018)

38. S. Zakharin, L. Yingying, I. Smyrnov, European Cooperation 10(29), 45-55 (2017)

39. International Monetary Fund Data (2020) https://www.imf.org/en/Data

40. The World Bank Data (2020) https://data.worldbank.org/

41. G. Abuselidze, L. Mamaladze, Lecture Notes in Computer Science 12253, 453-467 (2020) doi:10.1007/978-3-030-58814-4_32

42. G. Abuselidze, A. Slobodianyk, E3S Web of Conferences 210, 15016 (2020) doi:10.1051/e3sconf/202021015016

43. G. Abuselidze, A. Slobodianyk, Advances in Intelligent Systems and Computing 1258, 718-728 (2021) doi:10.1007/978-3-030-57450-5_61

44. L. Li, J. Liu, H. Long, W. de Jong, Y. C. Youn, Forest Policy and Economics 76, 7-13 (2017) doi:10.1016/j.forpol.2015.12.006

45. A. G. Raišienė, O. Yatsenko, V. Nitsenko, N. Karasova, A. Vojtovicova, Journal of International Studies 12(1), 193-207 (2019) doi:10.14254/2071-8330.2019/12-1/13

46. N. Davydenko, A. Dibrova, S. Onishko, L. Fedoryshyna, Journal of Optimization in Industrial Engineering 14(1), 177-181 (2021) doi:10.22094/JOIE.2020.677843

47. G. Abuselidze, A. Slobodianyk, E3S Web of Conferences 164, 09036 (2020) doi:10.1051/e3sconf/202016409036

48. S. Liu, China's Economy after the Financial Crisis Burst Economists' analysis of China's Economic Transformation (Foreign Languages Press, Beijing, 2012) 
49. Human Development Report. Beyond income, beyond averages, beyond today: Inequalities in human development in the 21st century (2019) http://hdr.undp.org/sites/default/files/hdr2019.pdf

50. The New World Order: China is Now Germany's Largest Trading Partner (Quarts, 2020) https://qz.com/975710/video-shows-delta-airlines-dal-removing-a-dad-andhisfamily-from-an-overnight-flight/

51. A. Slobodianyk, G. Abuselidze, E3S Web of Conferences 135, 01019 (2019) doi:10.1051/e3sconf/201913501019 